\title{
The manifold works of Prof. Michal Novak
}

\author{
Petr Novak and Norbert Zilka \\ Institute of Neuroimmunology, Slovak Academy of Sciences, Bratislava, Slovakia \\ E-mail: petr.novak@savba.sk \\ norbert.zilka@savba.sk
}

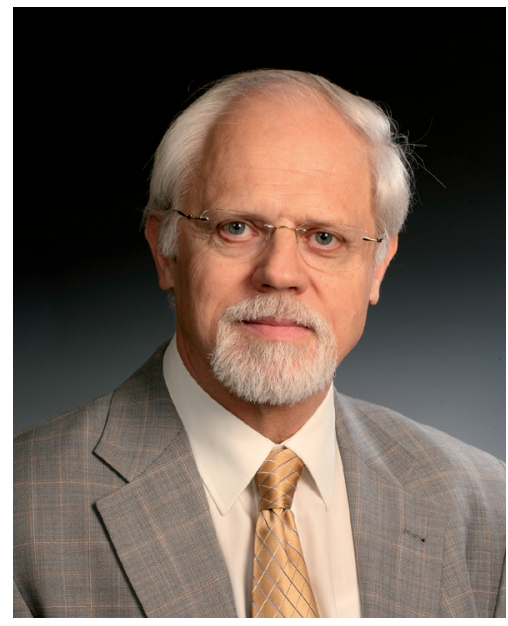

It is not common that a veterinary doctor with a passion for training and rehabilitating horses would go on to become a leading researcher into human dementias. But then it is not the common tales that stand out, but rather the exceptional ones that capture our attention and resonate within. While the numerous insights into equine

health and psychology prof. Michal Novak made during his early career at the Veterinary College in Kosice have gone largely unpublished, his track record in research of human neurodegeneration is well known.

Prof Novak's first international acclaim came in 1987 for his research into the pathogenesis of cystic fibrosis, in particular for his monoclonal antibody work (Dorin et al. 1987). Despite the shackles of the Iron Curtain, this work led to Michal Novak being invited to the MRC Laboratory of Molecular Biology in Cambridge, England, to apply his talents with antibodies in the field of Alzheimer's research. This gave Michal Novak the opportunity to work with giants in the field, such as the remarkably polyhistoric professor of psychiatry, sir Martin Roth, who began to build upon Alzheimer's original findings on neurofibrillary pathology, sir Aaron Klug, who received his Nobel Prize for work on crystallographic electron microscopy, and sir Cesar Milstein, honoured for the creation of hybridoma technology. It is most fitting then, that Michal Novak's approach towards immunological diagnostics and treatment of Alzheimer's disease (AD) and non-Alzheimer tauopathies would rely heavily on these technologies.

The research at MRC bore fruit soon - where Inge Grundke-Iqbal, Khalid Iqbal and Henryk M. Wisniewski identified tau protein as a component of neurofibrillary tangles in AD (Grundke-Iqbal et al. 1986), the Cambridge team showed this protein to be their principal constituent, and thus at the very core of a lesion that is central to $\mathrm{AD}$ (Wischik et al. 1988a, 1988b). From this moment onwards, prof. Novak's work was focused on the understanding of this complex protein, and how its dysfunction leads to neurodegeneration. The stay in the MRC Cambridge brought further understanding on this topic, especially the notion that tau in disease is post-translationally modified, and thus a distinct molecular and immunological entity from physiological tau (Jakes et al. 1991; Novak et al. 1991, 1993). Presently, it is increasingly becoming apparent that aberrant post-translational modification of CNS proteins is a common denominator of numerous neurodegenerative disorders.

Following his return to Slovakia in 1994, he pursued this line of research further. As the magnitude of the problem posed by dementing disorders became increasingly apparent (Ott et al. 2006), he saw a need to create an institution dedicated to their study - the Institute of Neuroimmunology of the Slovak Academy of Sciences. Founded in 1996 amidst massive layoffs at the academy, its creation was seen by some as audacious - but then, in the words of Theodore Roosevelt, "nothing in the world is worth having or worth doing unless it means effort, pain, difficulty". The new institute proved its mettle in due time, and was designated Centre of Excellence for $\mathrm{AD}$ and related disorders in 2004.

Observing that some research endeavours were best handled by an independent company, prof. Novak founded Axon Neuroscience in Vienna, Austria, in 1999. Over the

(C) The Authors 2021. This is an open access article under the terms of the Creative Commons Attribution-NonCommercial 4.0 International License (https://creativecommons.org/licenses/by-nc/4.0/), which permits non-commercial use, distribution, and reproduction in any medium, provided the original work is properly cited. 
following 20 years, it would deliver numerous pioneering discoveries. In 2006, his team conclusively proved that nonmutant truncated tau, exactly as seen in the paired helical filament core in $\mathrm{AD}$, is fully capable and sufficient to cause progressive lethal neurodegeneration, establishing the first rat model of tau pathology that develops mature tangles without using mutant tau (Zilka et al. 2006). The relevance of this discovery becomes apparent when one considers that mutations in tau protein cause tauopathies other than $\mathrm{AD}$, yet a majority of tau-targeted compounds for the treatment of $\mathrm{AD}$ are being developed utilising rodent models with tau mutations - thus, this novel line of rat models replicates AD tau pathology more faithfully than most.

With the world single-mindedly focused on the other main feature of Alzheimer's disease, amyloid- $\beta$, and most of the world's AD researchers firmly seated on the amyloid bandwagon (Blennov et al. 2006), Prof. Novak has adhered to his research into tau pathology as the lesion that is proximal to cognitive loss and disease progression. His persistence was vindicated by other groups that showed neurofibrillary pathology to be a condition sine qua non, and the most direct correlate and predictor of cognitive loss and brain atrophy in AD (Nelson et al. 2012; Murray et al. 2015; La Joie et al. 2020). In plain words, one's brain can be clogged with amyloid- $\beta$ without pronounced effect on cognition, but truly rare is the person with a brain full of tau lesions whose faculties are even somewhat intact.

A major milestone was the initiation of the world-first immunotherapy trial aimed at tau pathology in $\mathrm{AD}$ in 2013. This forerunner vaccine, AADvac1, is designed to induce antibodies that are specific to pathological tau protein via displaying a conformational tau epitope that is found in $\mathrm{AD}$ in the domain of tau that is necessary for aggregation and propagation of tau pathology. The aim is to prevent tau aggregation and propagation of tau pathology, and to label pathological tau moieties for removal by microglia (Kontsekova et al. 2014a, 2014b; Novak et al. 2018a). The in vitro and animal findings confirmed the expectations. While willing to take up tau on their own, with the aid of antibodies, microglia display a far greater appetite for the pathological protein, while neurons are shielded from tau uptake; treated transgenic animals develop less neurofibrillary lesions, and deposit far lower amounts of insoluble tau in their brains (Kontsekova et al. 2014b; Weisova et al. 2019; Zilkova et al. 2020). In humans, treatment with AADvac1 was remarkably safe; despite the immune senescence that is common in the elderly, almost all AD patients treated with AADvac1 developed the desired IgG1-dominated antibody response (Novak et al. 2017). Considering the number of tau-targeted immunotherapies that entered clinical development following the initiation of the AADvac1 program, it is evident that the encouraging early safety findings of AADvacl gave other groups the courage to move ahead with their own compounds.

Similarly, the long-term safety and immunogenicity results were encouraging; this is vital, as $\mathrm{AD}$ patients can be expected to require treatment for years or decades. Similarly encouraging were results suggesting that patients with higher levels of AADvac1-induced antibodies display slower disease progression and less brain atrophy (Novak et al. 2018b). Last but not least, it became apparent that the antibody response induced by the vaccine could target tau not only in $\mathrm{AD}$, but non-AD tauopathies as well, thus opening an avenue to aid patients suffering from these rare 'orphan' diseases as well (Novak et al. 2018b).

Based on these positive findings, AADvac1 was advanced into phase 2 development. The results of this study aligned with the hypothesis - the vaccine was safe and immunogenic; in comparison to patients on placebo, the AADvac1treated patients displayed lower levels of pathological tau and phospho-tau in the cerebrospinal fluid, and lower levels of neurofilament light chain protein (a neurodegeneration marker) in the blood, and less white matter degeneration in vital tracts such as the fornix. In patients who were most likely to have bona fide $\mathrm{AD}$, treatment slowed clinical decline (Novak et al. 2021). Further longitudinal studies on a sizable $\mathrm{AD}$ patient cohort are necessary to provide unequivocal evidence of clinical benefit - then, we shall know the outcome of this pioneering journey.

In addition to his personal effort towards finding a cure for AD, prof. Michal Novak understood that this is an endeavour greater than any one human can bring to fruition. Every step along the way, he has fostered cooperation and created structures that would help researchers, clinicians, caregivers, and patients, to coordinate their efforts to combat AD. Especially worthy of a mention are the founding of the Slovak Alzheimer's Society in 1998, and the founding of the MEMORY Centre in Bratislava in 2002 - a facility specialised in care, prevention, diagnostics and education for people with memory disorders and AD and their caregivers. The centre is a self-sustaining pilot project that aims to serve as a template for other such facilities in Slovakia. In line with his emphasis on cooperation, Prof. Novak has consistently been a clarion voice for cooperation and unity within the Academy, to make it more than the sum of its parts and a force to be reckoned with. Remarkable also, are his efforts to create a national Alzheimer plan for Slovakia starting in 2016.

The list of lectures he has been invited to speak at, the many awards, and similar would exceed the scope of this article - suffice to say, his work drew abundant international acclaim, including invitations to speak at the WHO forum, and receiving His Highness Sheikh Sabah Al-Ahmad AlJaber Al-Sabah's Prize for Research in Health Care for the Elderly and in Health Promotion. 
In this year, Prof. Novak received the prestigious award Khalid Iqbal Lifetime Achievement Award of the Alzheimer's Association USA - for his crucial role in the discovery of tau as the constituent of neurofibrillary tangles and the protein's major role in Alzheimer's disease.

The teachings of Prof. Novak's work are perhaps best studied in detail within a more expansive text; thus, we will conclude with a quote from Richard P. Feynman, that best summarises Michal Novak's approach based on intellectual humility, scientific rigor, and a strict natural selection process applied to every hypothesis - "It doesn't make any difference how beautiful your guess is, it doesn't matter how smart you are who made the guess, or what his name is... If it disagrees with experiment, it's wrong. That's all there is to it."

\section{References}

Blennow K, de Leon MJ, Zetterberg H (2012): Alzheimer's disease. Lancet 368, 387-403 https://doi.org/10.1016/S0140-6736(06)69113-7

Dorin JR, Novak M, Hill RE, Brock DJ, Secher DS, van Heyningen V (1987): A clue to the basic defect in cystic fibrosis from cloning the CF antigen gene. Nature 326, 614-617

https://doi.org/10.1038/326614a0

Grundke-Iqbal I, Iqbal K, Quinlan M, Tung XC, Zaidi MS, Wisniewski HM (1986): Microtubule-associated protein tau. A component of Alzheimer paired helical filaments. J. Biol. Chem. 261, 6084-6089 https://doi.org/10.1016/S0021-9258(17)38495-8

Jakes R, Novak M, Davison M, Wischik CM (1991): Identification of 3- and 4-repeat tau isoforms within the PHF in Alzheimer's disease. EMBO J. 10, 2725-2729

https://doi.org/10.1002/j.1460-2075.1991.tb07820.x

Kontsekova E, Zilka N, Kovacech B, Skrabana R, Novak M (2014a): Identification of structural determinants on tau protein essential for its pathological function: novel therapeutic target for tau immunotherapy in Alzheimer's disease. Alzheimers Res. Ther. 6, 45 https://doi.org/10.1186/alzrt277

Kontsekova E, Zilka N, Kovacech B, Novak P, Novak M (2014b): First-in-man tau vaccine targeting structural determinants essential for pathological tau-tau interaction reduces tau oligomerisation and neurofibrillary degeneration in an Alzheimer's disease model. Alzheimers Res. Ther. 6, 44 https://doi.org/10.1186/alzrt278

La Joie R, Visani AV, Baker SL, Brown JA, Bourakova V, Cha J, Chaudhary K, Edwards L, Iaccarino L, Janabiet M, et al. (2020): Prospective longitudinal atrophy in Alzheimer's disease correlates with the intensity and topography of baseline tau-PET. Sci. Transl. Med. 12, eaau5732 https://doi.org/10.1126/scitranslmed.aau5732

Murray ME, Lowe VJ, Graff-Radford NR, Liesinger AM, Cannon A, Przybelski SA, Rawal B, Parisi JE, Petersen RC, Kantarci K, et al. (2015): Clinicopathologic and 11C-Pittsburgh compound
B implications of Thal amyloid phase across the Alzheimer's disease spectrum. Brain 138, 1370-1381 https://doi.org/10.1093/brain/awv050

Nelson PT, Alafuzoff I, Bigio EH, Bouras C, Braak H, Cairns NJ, Castellani RJ, Crain BJ, Davies P, Del Tredici K, et al. (2012): Correlation of Alzheimer disease neuropathologic changes with cognitive status: a review of the literature. J. Neuropathol. Exp. Neurol. 71, 362-381 https://doi.org/10.1097/NEN.0b013e31825018f7

Novak M, Jakes R, Edwards PC, Milstein C, Wischik CM (1991): Difference between the tau protein of Alzheimer paired helical filament core and normal tau revealed by epitope analysis of monoclonal antibodies 423 and 7.51. Proc. Natl. Acad. Sci. USA 88, 5837-5841 https://doi.org/10.1073/pnas.88.13.5837

Novak M, Kabat J, Wischik CM (1993): Molecular characterization of the minimal protease resistant tau unit of the Alzheimer's disease paired helical filament. EMBO J. 12, 365-370 https://doi.org/10.1002/j.1460-2075.1993.tb05665.x

Novak P, Schmidt R, Kontsekova E, Zilka N, Kovacech B, Skrabana R, Vince-Kazmerova Z, Katina S, Fialova L, Prcina M, et al. (2017): Safety and immunogenicity of the tau vaccine AADvac1 in patients with Alzheimer's disease: a randomised, double-blind, placebo-controlled, phase 1 trial. Lancet Neurol. 16, 123-134 https://doi.org/10.1016/S1474-4422(16)30331-3

Novak P, Cehlar O, Skrabana R, Novak M (2018a): Tau conformation as a target for disease-modifying therapy: The role of truncation. J. Alzheimers Dis. 64, 535-546 https://doi.org/10.3233/JAD-179942

Novak P, Schmidt R, Kontsekova E, Kovacech B, Smolek T, Katina S, Fialova L, Prcina M, Parrak V, Dal-Bianco P, et al. (2018b): FUNDAMANT: an interventional 72-week phase 1 followup study of AADvac1, an active immunotherapy against tau protein pathology in Alzheimer's disease. Alzheimers Res. Ther. 10, 108 https://doi.org/10.1186/s13195-018-0436-1

Novak P, Kovacech B, Katina S, Schmidt R, Scheltens P, Kontsekova E, Ropele S, Fialova L, Kramberger M, PaulenkaIvanovova N, et al. (2021): ADAMANT: a placebo-controlled randomised phase 2 study of AADvac1, an active immunotherapy against pathological tau in Alzheimer's disease. Nat. Aging 1, 521-534

https://doi.org/10.1038/s43587-021-00070-2

Ott A, Breteler MM, van Harskamp F, Claus JJ, van der Cammen TJ, Grobbee DE, Hofman A (1995): Prevalence of Alzheimer's disease and vascular dementia: association with education. The Rotterdam study. BMJ 310, 970-973 https://doi.org/10.1136/bmj.310.6985.970

Weisova P, Cehlár O, Škrabana R, Žilková M, Filipčík P, Kováčech B, Prčina M, Wojčiaková L', Fialová L, Smolek T, et al. (2019): Therapeutic antibody targeting microtubule-binding domain prevents neuronal internalization of extracellular tau via masking neuron surface proteoglycans. Acta Neuropathol. Commun. 7, 129 https://doi.org/10.1186/s40478-019-0770-y

Wischik CM, Novak M, Thogersen HC, Edwards PC, Runswick MJ, Jakes R, Walker JE, Milstein C, Roth M, Kluget A (1988a): Isolation of a fragment of tau derived from the core of the 
paired helical filament of Alzheimer disease. Proc. Natl. Acad. Sci. USA 85, 4506-4510

https://doi.org/10.1073/pnas.85.12.4506

Wischik CM, Novak M, Edwards PC, Klug A, Tichelaar W, Crowther RA (1988b): Structural characterization of the core of the paired helical filament of Alzheimer disease. Proc. Natl. Acad. Sci. USA 85, 4884-4888 https://doi.org/10.1073/pnas.85.13.4884

Zilka N, Filipcik P, Koson P, Fialova L, Skrabana R, Zilkova M, Rolkova G, Kontsekova E, Novak M (2006): Truncated tau from sporadic Alzheimer's disease suffices to drive neurofibrillary degeneration in vivo. FEBS Lett. 580, 3582-3588 https://doi.org/10.1016/j.febslet.2006.05.029

Zilkova M, Nolle A, Kovacech B, Kontsekova E, Weisova P, Filipcik P, Skrabana R, Prcina M, Hromadka T, Cehlar O, et al. (2020): Humanized tau antibodies promote tau uptake by human microglia without any increase of inflammation. Acta Neuropathol. Commun. 8, 74

https://doi.org/10.1186/s40478-020-00948-Z 